\title{
DIURNAL DYNAMICS OF THE PHOSPHATE LEVEL IN THE RUMEN FLUID OF GOATS
}

\author{
M. MAROUNEK, S. BARTOS
}

Institute of Animal Physiology and Genetics, Czechoslovak Academy of Sciences, 25161 Prague

\author{
Received November 16, 1978
}

\begin{abstract}
Marounek M., S. Bartoš: Diurnal Dynamics of the Phosphate Level in the Rumen Fluid of Goats. Acta vet. Brno, 47, 1978: 123-126.

The free phosphate concentration in the rumen fluid is highest in fasting goats (about $40 \mathrm{mmol} / \mathrm{l}$ ). It falls during and after feeding and attains the minimum (about $30 \mathrm{mmol} / \mathrm{l}$ ) about 4 hours after the start of feeding, i. e. at the time of intensive fermentation. The course of the phosphate level can be satisfactorily attributed to the different permeability of the rumen wall for water and phosphate ions.

The bound phosphate concentration does not exceed $10 \mathrm{mmol} / \mathrm{l}$. After an initial drop it rises and attains peak value about 7 hours after the start of feeding, i. e. at the time of the maximum fermentation rate, when the greatest increase in microbial mass occurs in the rumen.
\end{abstract}

Rumen fluid, phosphorus metabolism, phosphate, goats.

The high phosphates concentration in rumen fluid is a manifestation of intensive participation by phosphorus compounds in metabolism in the rumen. Their role is characterized by the release and degradation of phosphorus compounds contained in plants, by rich salivary phosphate secretion, by participation in regulation of the $\mathrm{pH}$ and incorporation into the cells of symbiotic microorganisms. Free phosphates preponderate over the bound form in rumen fluid i. e. $\mathrm{H}_{2} \mathrm{PO}_{4}-$ and $\mathrm{HPO}_{4}$-- anions over phosphoric acid esters. The proportion of the two forms has not yet been exactly determined, however, and we likewise do not know exactly the factors which act on the rumen phosphate level, how this level changes in relation to time and the associations and significance of the changes. The opinions of different authors in this respects are at variance. According to some, the free phosphate concentration is not affected by the composition of the diet (Drozhdenko and Zhilenko, 1973) or the amount consumed (Prasad and Raghawa, 1974). Other studies show that a high dietary phosphorus intake also raises the phosphate concentration in the rumen fluid (e. g. Nel 1974). Endogenous phosphorus secretion into the rumen is decreased by a defficiency of phosphorus probably as a result of decreased plasma inorganic phosphate levels (Preston and Pfander, 1964). The concentration of phosphate in the rumen fluid is also a function of physical preparation of the diet. The question of diurnal changes in the free phosphate lovel in the rumen fluid is similarly unresolved. Volsky and Gzhitsky (1964) found the maximum concentration 2-3 hours after a feed, but Prasad and Raghawa (1974) and Sawa et al. (1974) did not find the time of collection decisive. Conversely, Pálfy et al. (1964) and Nel (1974) found the maximum concentration prior to feeding. We therefore decided to investigate the 24-hour dynamics of the phosphate level in goats fed once a day on concentrate and hay. In addition to free phosphate we determined total phosphate and the difference (i. e. bound phosphate). We also measured the $\mathrm{pH}$ in samples of rumen fluid and determined the amount of volatile fatty acids - the main fermentation product.

\section{Materials and Methods}

Goats with a permanent rumen fistula were used for the experiments. During the experiment the animals were fed once a day on $0,5 \mathrm{~kg}$ barley concentrate and hay ad libitum. Feeding time was always confined to 7 to 9 a. $\mathrm{m}$. but water was always available. Samples were collected with a stom- 
ach tube with $0.25 \mathrm{~mm}$ openings, which captures large food remains and at the same time lets even the largest forms of protozoans through. The fluid thus obtained represents the medium in which the majority of metabolic reactions in the rumen take place and its composition is usually sufficient for a description of fermentation at the instant in question. Fluid

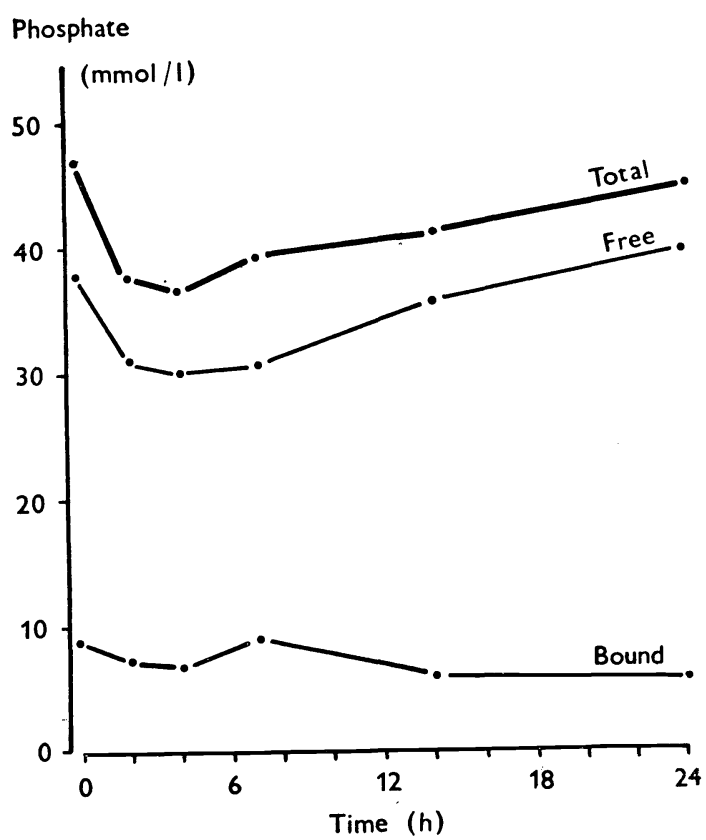

Fig. 1.

Course of free phosphate level, volatile fatty acid level and $\mathrm{pH}$ in rumen fluid of goats fed once daily.

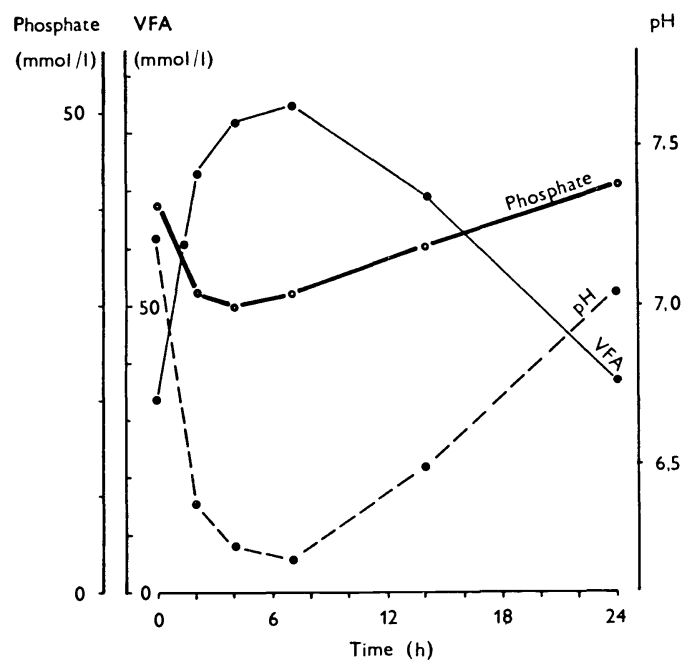
samples were collected $0,2,4,7,14$ and 24 hours from the start of feeding, i. e. at asymmetrical times, with emphasis on detection of the peak in fermentation.

After spinning off microorganisms and food particles, free phosphate was determined in the rumen fluid supernatant by the method of Fiske and Subba Row (1925). The same method was used for the determination of total phosphate in rumen fluid hydrolysed with $6 \mathrm{~N} \mathrm{HCl}$.

The $\mathrm{pH}$ was measured potentiometrically with a combined electrode. Volatile fatty acids were assayed by the titration method of Friedemann and Brook (1938) after distillation from samples preserved with mercury chloride.

\section{Results}

As seen from Fig. 1, free phosphate level was highest in fasting animals (about $40 \mathrm{mmol} / 1$ ) and fell during feeding, attaining the minimum (about $30 \mathrm{mmol} / 1$ ) four hours after the start of feeding. Comparison with the course of the volatile fatty acids curve shows that the time of maximum drop in the free phosphate concentration coincided with the time of maximum fermentation. The results are the means of eight experiments.

The courses of the total and free phosphate levels and their difference, bound phosphate, are plotted in Fig. 2. The course of the total phosphate level was determined by that of its main component - free phosphate. The bound phosphate level did not exceed $10 \mathrm{mmol} / 1$. After an in-

Fig. 2.

Course of total, free and bound phosphate levels in rumen fluid of goats fed once daily. 
itial drop it rose and attained peak value about 7 hours after the start of feeding, i. e. at the time of the maximum rate of fermentation. The results are the means of six experiments.

\section{Discussion}

The free phosphate dynamics we found in goat rumen fluid correspond to the free phosphate dynamics found by Nel (1974) in sheep. The course of the curve is hard to interpret. The free phosphate concentration evidently depends on alimentary phosphorus intake, as demonstrated by $\mathrm{Nel}$. We also concur with the view that a decisive amount of phosphate enters the rumen by the recycling route, i. e. chiefly in the saliva. The course of the curve nevertheless remains unexplained. At the time when phosphorus is taken in the food and released from plant tissues, its concentration in the rumen fluid falls instead of rising as one would have expected. Its lowest points is reached at the time of the maximum fermentation rate. Conversely, in the hours of fasting, when one would hardly expect increased salivation or stimulation of phosphate recycling, its concentration rises.

In our opinion, the level of alimentary phosphorus intake acts only of the mean phosphate concentration in the rumen fluid. Phosphate recycling associated with salivation is continuous in ruminants and is not known to undergo any marked changes. We can explain the typical course of the curve quite well if we bear in mind the different permeability of the rumen wall for water and phosphate ions. Water transport across the rumen wall is considerable and in small ruminants it amounts, in both directions, to about $501 / 24$ hours (Engelhardt 1970). On the other hand, the permeability of the rumen wall for phosphate ions is small (Wright 1955 and other autors). That means that the free phosphate concentration should fall when more water is transported into the rumen and, vice versa, that it should rise when more water is transported out of the rumen (i. e. when fermentation is virtually over). This explanation fits the experimental findings.

The absolute free and total phosphate levels in rumen fluid are fairly high. Our findings in sheep (in other experiments) were systematically lower. We also found a low free phosphate concentration in the rumen fluid of fattened bullocks (18 determinations, mean $9.5 \pm 3.4 \mathrm{mmol} / \mathrm{l}$ ). We did not investigate these interspecies differences any further, but, in agreement with the findings of Volsky (1965), they seem to be associated with the rate of metabolism in the rumen. The rate of metabolism in the rumen of small ruminants is higher than in large ruminants.

The explanation of the shape of the bound phosphate curve presents no difficulties. The maximum at the peak fermentation time, about 7 hours after the start of feeding, is associated with extensive microbial cell proliferation at that time. The amount of bound phosphate and changes in its concentration can be regarded as a rough indicator of the biosynthetic activity of rumen microorganisms.

\section{Čtyřiadvacetihodinová dynamika fosfátu $v$ bachorové tekutině koz}

Koncentrace volného fosfátu $\mathrm{v}$ bachorové tekutině je nejvyšší u lačných koz (asi $40 \mathrm{mmol} / \mathrm{l}$ ). Během krmení a po krmení klesá. Minima (asi $30 \mathrm{mmol} / \mathrm{l}$ ) dosahuje ve 4 . hodině od začátku krmení, tedy $\mathrm{v}$ době intenzívní fermentace. Průběh 
hladiny fosfátu lze dobře vysvětlit rozdílnou propustností bachorové stěny vưči vodě a fosfátovým iontům.

Koncentrace vázaného fosfátu nepřekračuje $10 \mathrm{mmol} / 1$. Po počátečním poklesu roste a vrcholi kolem 7 . hodiny od začátku krmení, tj. $v$ době nejvyšší intensity fermentace, $k d y$ dochází $\mathrm{k}$ největšímu nárůstu hmoty bachorových mikroorganismů.

\section{Суточная динамика фосфата в жидкости рубца коз}

Концентрация свободного фосфата в жидкости рубца максимальна у голодных коз (около 40 ммол/л). В процессе кормления у после него она поднимается. Минимума (около 30 ммол/л) она достигает 4 часа после начала кормления, следовательно, в период интенсивной ферментации. Характеристику уровня фосфата можно хорошо объяснить разной проницаемостью стены рубца по отношению к воде и ионам фосфата.

Концентрация несвободного фосфата не превышает 10 ммол/л. После первоночального понижения она растет и пика достигает приблизительно 7 часов после начала кормления, т. е. в период максимальной интенсивности ферментации, когда умеет место наивысший рост массы микроорганизмов рубца.

\section{References}

DROZHDENKO, A. D. - ZHILENKO, V. A.: Phosphorus metabolism in the rumen and duodenal chyme of calves during feeding of various types of rations. 1973. In: Chem. Abstr., 82, (13): $85013 \times, 1975$.

ENGELHARDT, W.: Movement of water across the rumen epithelium. In: Phillipson et al.: Physiology of digestion and metabolism in the ruminant, pp. 132-146. Oriel Press, Newcastle, England, 1970.

FISKE, C. H. - SUBBA ROW Y.: The colorimetric determination of phosphorus. J. Biol. Chem., 66, 375, 1925.

FRIEDEMANN, T. E. - BROOK, T.: The identification and determination of volatile alcohols and acids. J. Biol. Chem., 123, $1961-184,1938$.

NEL, J. W.: The pattern of calcium, phosphorus and magnesium in rumen fluid and blood serum of sheep on restricted intake and duodenal and ruminal supplementation of phosphates. Agroanimalia, 6, 103-112, 1974.

PÁLFY F. Yu. - BALAZH, Yu. Yu. - KOVALSKY, E. N. - SLABICKY, Y. I.: Vlijanije skarmlivania različnych vidov rastitělnych bělkov na sutočnyje izmeněnija biochimičeskich pokazatělej v soděržimom rubca korov. III. respubl. nauč. konferencija po fiz. i bioch. s-ch. životnych. Lvov 1964. Tězisy dokladov str. $269-270$.

PRASAD, V. L. - RAGHAWA, N. G. V.: Effect of the level of intake on reticulo-rumen cations. of cattle and buffaloes. Indian. J. Anim. Sci., 43 (8): 693-698, 1974.

PRESTON. R, L. - PFANDER, W. H.: Phosphorus metabolism in lambs fed varying phosphorus intakes. J. Nutr., 83. 1964: 369-378.

SAWA, A. - SENSHU, T. - MATSUMOTO, T.: Concentration of macro-minerals in the rumen fluid of sheep. Nippon Chikusan Gakkai-ho, 45 (7): 387-395, 1974.

VOLSKY, N. N.: Fosfornyje sojediněnija židkosti rubca krupnovo rogatovo skota. Avtoreferat dissertacii. Lvovskij zooveterinarnyj institut, Lvov 1965.

VOLSKY, N. N. - GZHITSKI, S. Z.: Vlijanije někotorych faktorov na koncentraciju fosfornych sojediněnij v soděržimom rubsa krupnovo rogatovo skota. III. respubl. nauč. konf. po fiz. i bioch. s.-ch. život. Lvov 1964, Těz. dokladov, str. 53-54.

WRIGHT, E.: Site of phosphorus absorption in the sheep. Nature, 176: 351-352, 1955. 